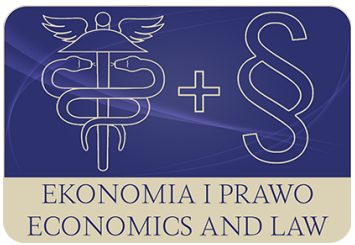

EKONOMIA I PRAWO. ECONOMICS AND LAW

Volume 19, Issue 2, June 2020

p-ISSN 1898-2255, e-ISSN 2392-1625

www.economicsandlaw.pl

EKONOMIA I PRAWO
ECONOMICS AND LAW

ORIGINAL ARTICLE

received 18.03.2020; revised 14.05.2020; accepted 30.06.2020

Citation: Dziawgo. L. (2020). Political risk on Polish capital market. Ekonomia i Prawo. Economics and Law, 19(2): 249-259. doi:10.12775/EiP.2020.017.

\title{
Political risk on Polish capital market
}

\section{LESZEK DZIAWGO}

Nicolaus Copernicus University in Toruń, Faculty of Economic Sciences and Management, Department of Financial Management, ul. Gagarina 13a, 87-100 Toruń, Poland

๑ldziawgo@econ.umk.pl

(D) orcid.org/0000-0003-3666-7651

\begin{abstract}
Motivation: The problem of political risk occurrence in the functioning of the economy should be subjected to scientific analysis. At the same time, various manifestations of political risk, its intensity and effects can be pointed out. Since the capital market is also an essential part of the modern economy, the following relationships should be analyzed: political risk — capital market.

Aim: The purpose of the article is to draw attention to political risk on the Polish capital market and to present the results of own research on this issue.

Results: The article describes selected aspects of political risk on the Polish capital market. The analysis includes both theoretical and empirical approach. An important part of the study is the presentation of the results of own research conducted on a sample of individual investors in 2014 and 2020 with the support of the Polish Association of Individual Investors. In the opinion of individual investors, the negative impact of political risk on the Polish capital market is increasing.
\end{abstract}

Keywords: political risk; capital market; individual investors

JEL: D53; D81; E44; G18; P16

\section{Introduction}

Political risk in the functioning of modern economies must not only be considered, but also regarded as one of the larger threats. The scale of the politics impact on the functioning of the economy, makes it possible to define this state almost as the dominance of politics over the economy. Probably the consequence are serious disturbances in the rationality of the management process on a scale from global to local. It can be presumed that the cause of many economic phe- 
nomena and processes, including crisis, is among others just the effect of political decisions. The key problem is not only the quality of political decisions, but also their predictability, as well as the period, scope and, above all, the effects of their impact.

In connection with the above, one can formulate a basic research problem: what are the laws of functioning of the modern economy, including the capital market? To what extent are these economic rights and to what extent political rights? It is a matter of fundamental importance for the economy, society and the science of economics. In other words, one should strive to indicate equilibrium, i.e. to set a point of balance between politics and the economy, and thus between the state and the market.

The aim of the article is to indicate the existence of political risk on the example of the Polish capital market and to present the results of own research. The scope of the analysis was focused on the stock market due to its key importance for the capital market.

Bearing in mind the differences between the concepts of risk and uncertainty, the concept of political risk is used in the article due to the greater popularity of this formulation on the financial market.

The theoretical part was devoted to considerations on the role of politics in the economy, the concept of political risk and political uncertainty, as well as the possibilities of redefining the concept of economics due to the dependence of the economy on politics.

However, the empirical part of the article presents examples of the occurrence of political risk on the Polish capital market. The article includes the result and research carried out on a targeted sample of Polish individual investors. The research was conducted in 2014 and 2020 with the support of the Association of Individual Investors (SII).

\section{Literature review}

Political risk in the economy has long been a subject of scientific interest. It is analyzed taking into account many criteria (e.g. domestic, international, developed and developing countries, foreign investment, international trade, international institutions). Sottilotta (2013, pp. 3-4) identified following definitions groups of political risk: (1) as non-economic risk; (2) as unwanted government interference with business operations; (3) as probability of companies' operations by political forces or events; (4) as fluctuations in the business environment originating from political change, which affect the profits or the objectives of a firm; (5) as related to political instability and radical political change in the host country.

Political risk is also analyzed in relation to the financial market as general, it means: political risk and business profits (Henisz et al, 2010, pp. 1-8), political risk and financial obligations (Hoti, 2004, p. 1), including banking (Curetti, 2013, pp. 1-43; Diamote et al., 1996, pp. 71-76; Papaioannou, 2009, pp. 
269-281), as well as the capital market (Lensink et al., 2000, pp. 73-92; Loikas, 2003). The topic of measuring political risk (EY, Firm, Learning to fly) is considered likewise.

Furthermore, World Bank Group indicates on political risk in several dimensions: transfer and convertibility restrictions, expropriation, breach of contract, non-honoring of sovereign financial obligations, terrorism, war, civil disturbance, other adverse regulatory changes (Villar \& Jensen, 2011, p. 21).

It should also be emphasized that for years, attention has also been paid to the problem of distinguishing between the concepts of risk and uncertainty (Knight, 1921; Tversky et al., 1995, pp. 269-283). These considerations can also be applied to the capital market (EY, 2019; Hassan et al., 2019, pp. 21352202; Jarvis, 2007, pp. 5-21).

In the scope of literature review, both scientific and business reports of recognized institutions can be mentioned.

\section{Methods}

The following methods were used in the study: analysis of the literature of the subject, descriptive and comparative analysis as well as questionnaire methods.

Own research was conducted twice on a targeted sample of individual investors with the support of the Polish Association of Individual Investors. In 2014, the sample of respondents included 428 investors, while in 2020 had 306 investors.

\section{Results}

\subsection{Between politics and economy: theoretical approach}

In the functioning of societies, politics and the economy have always been inextricably linked. One can only consider to what extent, when, where and for what reasons politics dominated the economy or vice versa. That is the contentious issue of what are the interactions between politics and the economy. This is even more relevant today.

The minimum scope of impact of the policy on the economy should be determined by three basic actions of appropriate quality:

- lawmaking,

- law enforcement,

- public finance management.

Meanwhile, it seems that the role of politics in the economy is definitely increasing. The modern world provides irrefutable evidence that politics goes beyond the above-mentioned ranges of activities. To some extent this can be justified (e.g. important social or security reasons). What is more, on the ba- 
sis of existing knowledge and experience, it can be concluded that the pursuit of the state of the free market in terms of absolute is both impossible and pointless. This is a separate topic for serious consideration.

However, regardless of the motives for political action, the possibility of political risk in the functioning of the economy, including the capital market, should be pointed out. It would mean disrupting the process of rational management.

Political risk in the economy is more or less felt. Financial markets are a particularly excellent example of such a rapid response. Actions or even just declarations of politicians are able to cause sudden and serious changes in prices of instrument s financial.

First of all, it should be noted that the analysis of the impact of policy hand on the functioning of financial markets, including the stock market, is a major scientific challenge. It can be pointed to a number of significant political risk characteristics that make it difficult to assess the situation (scheme 1).

Political decisions, which affect the capital market, could be justified due to officially indicated motives. However, unfortunately, it should be emphasized that political risk assessment is also extremely difficult, due to the possible existence of hidden factors that can influence political decisions. The following is an example catalog of hidden decision factors:

- political games,

- personal connections,

- ambitions,

- incompetence,

- corruption,

- no responsibility,

- foreign pressure.

Importantly, it must be assumed that, in general, it is hardly possible to determine the amount and strength of hidden political factors. Hence, the surprising public opinion and economists' decisions and their various effects on the economy. Precisely because of the occurrence of a number of hidden political factors, once again it seems reasonable to draw attention on assessment of the situation in terms of risk or uncertainty. This issue is discussed in more detail in the next section.

Both groups of factors, explicit and hidden, may result in formal or informal actions. In terms of formal activities, legislation, state administration activities or state shares in companies may be mentioned. However, in the area of informal activities, these that abuse or disregard the law could be mentioned.

In addition, it can also be seen that the intensity of political risk varies significantly. These may be serious, low-frequency events (elections, terrorist acts, conflicts) or frequent on a diversified, small scale (e.g. support from domestic or foreign public funds, corruption).

The scope of political risk on the financial market should also be indicated. It can occur at all levels of the economy: global, regional, national and local. 


\subsection{Scientific challenges}

It should be recognized that for the correct assessment of contemporary economic processes and phenomena on a global and local scale, it is necessary to take into account political risk. This is certainly a serious research challenge for the science of economics.

Given the above, a basic research problem should be formulated: what are the laws of the functioning of the modern economy? To what extent are these economic laws and to what extent are they political?

It is also important to pay attention to terminological issues. After the first, because of the hidden factors and the criterion of measurability should rather postulate that in place of the term 'political risks' to use the term 'political uncertainty' (scheme 2). It would be much better to write about this problem (Knight, 1921; LeRoy et al., 1987). However, due to the popularity of the financial market the term 'political risk' is just the term is used in this study.

Secondly, due to the growing dependence of the economy on politics, it might be (slightly contrary) to redefine the concept of learning economics. In the new approach, economics may become a science of para-economic justification for political decisions (Dziawgo, 2014, pp. 39-47).

The growing dominance of policy over the economy will require the development of existing methods and tools of economic analysis or the creation of new ones in order to control political risk. For example, credit rating or investor relations only to some extent respond to these new challenges (see more in Dziawgo, 2010; 2011).

In conclusion, the issue of political and economic interaction is certainly an important research area.

\subsection{State as shareholder: Polish capital market}

Poland is a country particularly exposed to very high political risk, both its own and foreign. Restricting only to domestic political risk, one can, unfortunately, point to its numerous and various examples. As mentioned earlier, these are cases of lawmaking, law enforcement and the sustainability of public finances. In the area of public finances, the state's activity on the capital market as an issuer of treasury bonds should also be taken into account. Another example is the act introducing extraordinary powers of the state towards selected enterprises, including listed companies (extraordinary rights known as 'golden shares') (Certain Investments Control Act, 2015). However, the presence of the state definitely goes beyond the acceptable minimum of activity. The activity of the state as the owner of serious blocks of shares in listed companies is particularly worrying.

The presentation of this part of the relationship 'state - capital market' must begin by recalling that Warsaw Stock Exchange, as a company, is jointly owned by the state. Similarly to the three key financial institutions PKO BP 
(banking), PeKaO (banking) and PZU (insurance). Moreover, in the WIG-20 index, state owns the majority of stake of shares in 10 companies. There are 13 such companies in the WIG-30 index. In addition to the companies listed in the above-mentioned indexes on the stock exchange, there are several other companies in which the main shareholder is the state. These include: Polski Holding Nieruchomości (PHN), PKP Cargo, Bank Ochrony Środowiska, Police, Polimex Mostostal. In addition, through subsidiaries of PKO BP, $\mathrm{PeKaO}$ and PZU as well as other state-owned companies, the state indirectly owns shares in many other listed companies (table 1).

Also, state foreign capital on the WSE generates some political risk. The companies CEZ and MOL are jointly owned by the Czech and Hungarian states, respectively. In addition, the involvement of international financial institutions in the shareholding of listed companies also creates political risk.

\subsection{Own research}

The issue of political risk is known among individual investors on the Polish capital market. This paper presents the results of research conducted in 2014 and 2020 according to the project and on behalf of the author and studies via Association of Individual Investors. In the first study, the targeted sample consisted of 428 investors, while in the second, 306 investors.

The obtained results are presented in chart 1 . The fact that already in 2014 up to $97 \%$ of investors had perception of political risk on the Polish market capital, should be considered as significant. Unfortunately, in 2020 the percentage of investors with this opinion increased to $98 \%$. Analyzing the answers given, it should be noted that in 2014 16\% of respondents noticed the existence of political risk on the Polish capital market, and $44 \%$ considered this risk to be felt. In 2020 , in both questions indicated, the distribution of answers was at the level of $11 \%$ and $27.5 \%$, respectively. However, this is not an improvement, as there has been a significant shift of opinion towards a more negative assessment of the occurrence of political risk on the Polish capital market. In 2014, 27\% of respondents were in favour of assessing political risk as 'disruptive', while $10 \%$ of those surveyed were in favour of 'destructive'. Unfortunately, the results of the research from 2020 in both categories indicated above indicated respectively $32 \%$ and as much as $27.5 \%$. It is therefore a definite worsening of the situation. Adding together the responses in both categories disrupting the market and destroying the market in the period 2014-2020 there was an increase from $37 \%$ to nearly as much as $60 \%$. In the investors' opinion, political risk is becoming an increasingly destabilizing factor in the capital market. It can therefore formulate a negative assessment of the impact of political risk, including the activity of the State in the capital market.

Political risk description on the Polish capital market may be supplemented by asking for an assessment of the presence of the state as a shareholder in listed companies. In both the 2014 and 2020 surveys, such a question was asked 
(chart 2). In 2014, there were 52\% positive indications as to the state's presence in listed companies, but in 2020 the percentage of positive responses dropped to $42 \%$. The result should be considered a significant change. Negative assessment of the presence of the State as a shareholder in listed companies increased from $38 \%$ in 2014 to $44 \%$ in 2020.

The results obtained, although they should be treated with caution, allow for a preliminary negative assessment of the impact of political risk. Political risk should be considered as a real threat to the functioning of the capital market.

\section{Conclusion}

Based on theoretical considerations and empirical material, the following conclusions can be made.

1. Political risk should be considered as a real threat to the modern economy, including the capital market. This study presents this issue on the example of the Polish capital market. The presented results of own research from 2014 and 2020 confirm the assessment of the situation.

2. Adequate analysis of economic processes and phenomena requires consideration of political risk, with the assessment of this risk being hampered or prevented by the presence of many hidden risk factors.

3. It should also be noted that the indicated problem fits into the broader topic of determining equilibrium - an appropriate balance between politics and the economy.

The topic of the occurrence of political risk on the capital market described in the article certainly remains an important and current scientific challenge that requires further research.

\section{References}

Curetti, E. (2013). Banks' foreign credit exposures and borrowers' rollover risks: Measurement, evolution and determinants. IMF Working Paper, 13(9). doi:10.5089/9781475544602.001.

Diamote, R.L. \& Liew, J.M. \& Stevens, R.S. (1996). Political risk in emerging and developer markets. Financial Analysts Journal, 52(3).

Dziawgo, D. (2010). Credit rating na międzynarodowym rynku finansowym. Warszawa: PWE.

Dziawgo, D. (2011). Relacje inwestorskie: ewolucja, funkcjonowanie, wyzwania. Warszawa: PWN.

Dziawgo, L. (2014). Political risk on the financial market: the problem of adequate scientific assessment of business operations: the naivety of economists. The Financial Internet Quarterly, 9(4).

EY. (2019). Political risk and corporate performance: mapping impact. Retrieved 07.03.2020 from https://ey.com. 
Hassan, T.A., Hollander, S., van Lent, L., \& Tahoun, A. (2019). Firm-level political risk: measurement and effects. The Quarterly Journal of Economics, 134(4). doi:10.1093/qje/qjz021.

Henisz, W.J., \& Zelner, B.A. (2010). The hidden risks in emerging markets, Harvard Business Review, April.

Hoti, S., \& McAleer, M. (2004). An empirical assessment of country risk ratings and associated models. Journal of Economic Surveys, 18(4). doi:10.1111/j.0950-0804.2004.00230.x.

Interia Biznes. (2020). Notowania GPW. Retrieved 09.03.2020 from https:// biznes.interia.pl.

Jarvis, D., \& Griffiths, M. (2007). Learning to fly: the evolution of political risk analysis. Global Society, 21(1). doi:10.1080/13600820601116435.

Knight, F.H. (1921). Risk, uncertainty and profit. Boston: Houghton Mifflin.

Lensink, R., Hermes, N., \& Murinde, V. (2000). Capital flight and political risk. Journal of International Money and Finance, 19(1). doi:10.1016/ S0261-5606(99)00034-0.

LeRoy, S.F., \& Singell, L.D. (1987). Knight on risk and uncertainty. Journal of Political Economy, 95(2).

Loikas, A. (2003). A government analysis of political risk: exploring equilibrium, instability, and pluralism at the local, national and supranational level in Europe. Unpublished doctoral dissertation, Turku School of Economics and Business Administration.

Papaioannou, E. (2009). What drives international financial flows: politics, institutions and other determinants. Journal of Development Economics, 88(2). doi:10.1016/j.jdeveco.2008.04.001.

Sottilotta, C.E. (2013). Political risk: concepts, definitions, challenges. LUISS School of Government Working Papers Series, SOG-WP6/2013.

Tversky, A., \& Fox, C.R. (1995). Weighing risk and uncertainty. Psychological Review, 102(2). doi:10.1037/0033-295x.102.2.269.

Ustawa z dnia 24 lipca 2015 r. o kontroli niektórych inwestycji [Certain Investments Control Act of 24 July 2015] (Dz.U. 2015 poz. 1272) (Poland).

Villar, D., \& Jensen, N. (2011). World investment and political risk 2011. Retrieved 10.05.2020 from http://documents.worldbank.org.

\section{Acknowledgements}

Author contributions: author has given an approval to the final version of the article.

Funding: this research was funded by the Nicolaus Copernicus University in Torun, Faculty of Economic Sciences and Management statutory sources. 


\section{Appendix}

Table 1.

State shares in selected listed companies (expected to 2020)

\begin{tabular}{|c|c|c|c|}
\hline Company name & Industry & Company include in WIG20 or WIG30 indexes & State shares (in \%) \\
\hline KGHM & mining & + & $31.79 \mathrm{SP}$ \\
\hline PKN Orlen & oil\&gas & + & $27.52 \mathrm{SP}$ \\
\hline Lotus & oil\&gas & + & $53.18 \mathrm{SP}$ \\
\hline PGNiG & oil\&gas & + & $71.00 \mathrm{SP}$ \\
\hline \multirow{2}{*}{ Tauron } & \multirow{2}{*}{ energy } & \multirow{2}{*}{+} & $30.06 \mathrm{SP}$ \\
\hline & & & 10.39 KGHM \\
\hline PGE & energy & + & $58.38 \mathrm{SP}$ \\
\hline PZU & insurance & + & $34.19 \mathrm{SP}$ \\
\hline PKO BP & banking & + & $29.43 \mathrm{SP}$ \\
\hline JSW & mining & + & $54.84 \mathrm{SP}$ \\
\hline PHN & real estate & - & $72.17 \mathrm{SP}$ \\
\hline Enea & energy & - & $51.50 \mathrm{SP}$ \\
\hline \multirow{2}{*}{ Polimex Mostostal } & \multirow{2}{*}{ architecture } & \multirow{2}{*}{-} & $6.37 \mathrm{PeKaO}$ \\
\hline & & & 65.93 Energa \\
\hline Warsaw Stock Exchange & capital market & - & $35.00 \mathrm{SP}$ \\
\hline Energa & energy & + & $51.51 \mathrm{SP}$ \\
\hline \multirow{2}{*}{ BOS } & \multirow{2}{*}{ banking } & \multirow{2}{*}{-} & 58.05 NFOŚiG \\
\hline & & & 5.54 PGL-LP \\
\hline PKP Cargo & transport & - & 33.01 PKP \\
\hline \multirow{2}{*}{ Azoty Group } & \multirow{2}{*}{ chemistry } & \multirow{3}{*}{+} & $33.00 \mathrm{SP}$ \\
\hline & & & 8.00 TFI PZU \\
\hline \multirow{3}{*}{ Police } & \multirow{3}{*}{ chemistry } & & 62.86 Azoty Group \\
\hline & & \multirow[t]{2}{*}{-} & 12.96 PZU OFE \\
\hline & & & $5.32 \mathrm{ARP}$ \\
\hline \multirow{2}{*}{ Pekao } & \multirow{2}{*}{ banking } & & 20.00 PZU \\
\hline & & & $12.80 \mathrm{PFR}$ \\
\hline
\end{tabular}

Notes:

SP — Treasury, ARP — Industrial Development Agency; NFOŚiGW — National Fund for Environmental Protection and Water Management, PGL-LP — State Forests, PFR — Polish Development Fund

Source: Own preparation based on Interia Biznes (2020). 


\section{Scheme 1.}

Political risk or political uncertainty: fundamental features

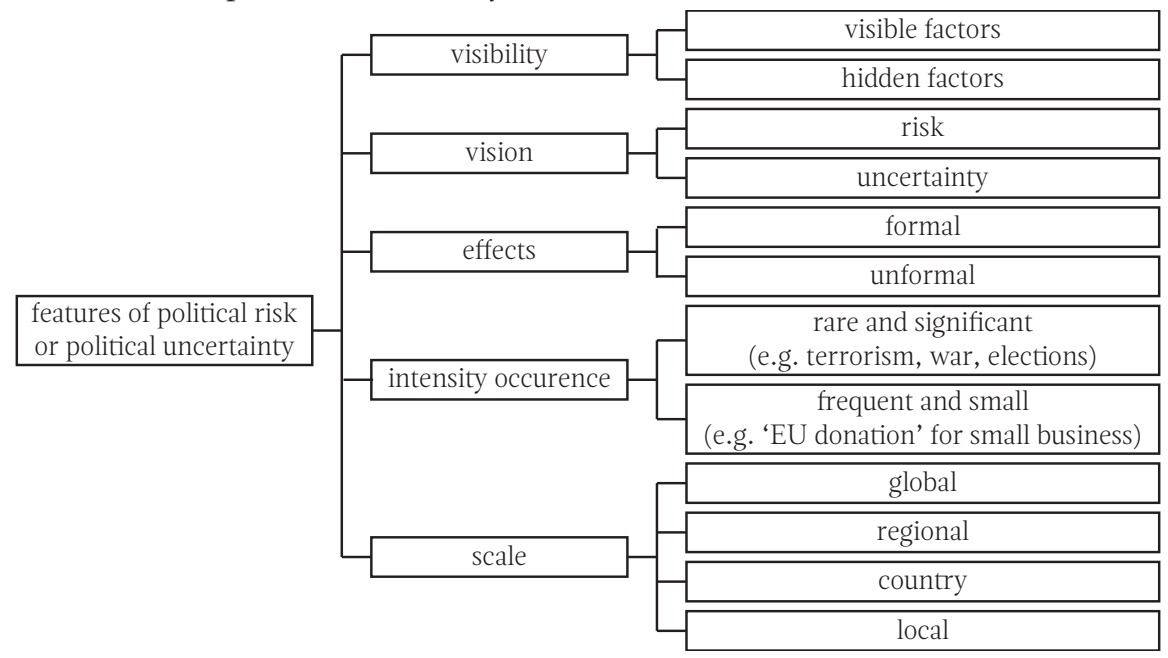

Source: Own preparation.

\section{Scheme 2.}

Political risk vs theory of economy

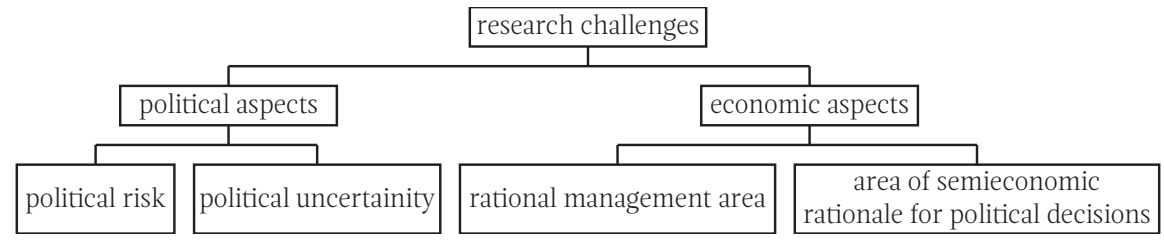

Source: Own preparation. 


\section{Chart 1.}

Distribution of answers to the question: How do you assess the intensity of domestic political risk on the Polish capital market? (in \%)

50

40

30

20

10

0
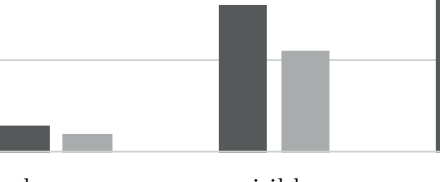

absence

visible

— 2014

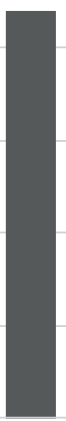

perceptive

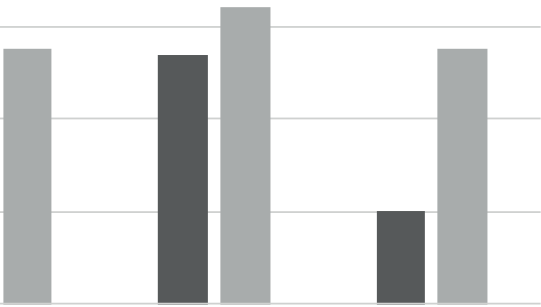

disrupting

2020

Notes:

2014: $\mathrm{N}=422 ; 2020: \mathrm{N}=306$ valid answers

Source: Own preparation.

\section{Chart 2.}

Distribution of answers to the question: Should the State Treasury have shares in listed companies? (in \%)

60

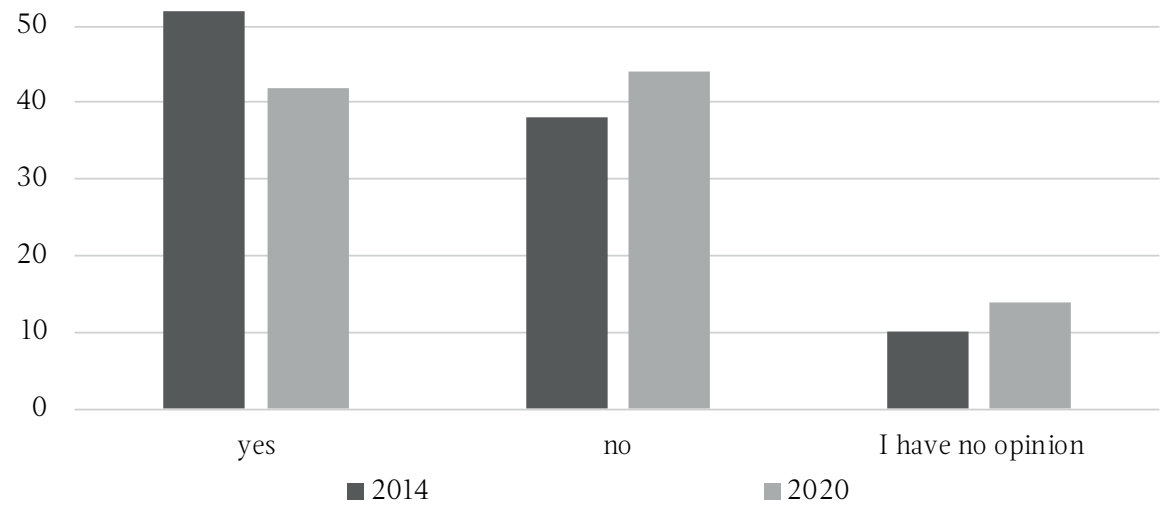

Notes:

2014: $\mathrm{N}=424 ; 2020: \mathrm{N}=306$ valid answers

Source: Own preparation. 
